\title{
Need for new reference curves for height
}

\author{
S CHINN, C E PRICE, AND R J RONA \\ Division of Community Health, United Medical and Dental Schools of Guy's and St Thomas's Hospitals, \\ St Thomas's Campus, London
}

SUmmary Data from the National Study for Health and Growth, on children aged from 4.0 to $12 \cdot 0$ years measured in 1972,1985 , and 1986 were used to assess whether new growth standards are required, and which subgroups of children might require separate standards. The change over this period, from just over half a centimetre in the youngest girls to over a centimetre in the oldest boys, warrants the use of revised reference curves, which are also needed for Afro-Caribbean children.

The standards, or reference curves, currently used in the clinical assessment of a child's height or rate of growth are based on data that were collected in 1959 , although they were updated in $1965 .{ }^{12}$ Mean height of children aged 5 to 11 years increased in the $1970 \mathrm{~s},{ }^{3}$ although no further increase was seen from 1979 to $1986,{ }^{4}$ and Voss et al suggested that new growth charts are now required, ${ }^{5}$ at least for the more affluent areas of southern England.

At an initial assessment a child's height will be assessed in relation to a reference group, and expressed as above or below some critical centile, such as the third. If the reference group is not representative of the population to which the children belong, the percentage of healthy children below the nominal third centile may differ from $3 \%$. If it is less than 3\%-for whatever reason-the screening process may be less sensitive than intended, and children may be excluded from follow up who would otherwise have been more fully investigated.

Trends over time and geographical variation are not the only reasons why new standards might be required. Rona and Chinn found children of AfroCaribbean origin to be about $3.5 \mathrm{~cm}$ taller, and Gujarati speaking children to be about $3 \mathrm{~cm}$ shorter, than white children on average. ${ }^{6}$ A screening procedure that used growth charts based on data from white children would therefore lack sensitivity for Afro-Caribbean children.

Goldstein and Tanner argued that there should be separate standards for subgroups of the population, and suggested standards conditional on sex, parental heights, family size, area of residence, and ethnic characteristics. ${ }^{7}$
The National Study for Health and Growth is a continuing surveillance study of children most of whom are aged from 5 to 11 years. Standards for attained height constructed from data collected in 1972 were found to be close to the Tanner standards. ${ }^{8}$ Data on a comparable sample were available from the 1986 survey, and on ethnic minority and inner city children from 1985 . The aim of this analysis was to ascertain whether new reference curves are required, and to assess the relative importance of the grouping variables suggested by Goldstein and Tanner. ${ }^{7}$

\section{Subjects and methods}

In 1972 the National Study for Health and Growth was carried out in 22 areas of England and six in Scotland, selected by stratified random sampling of employment exchange areas, and weighted towards poorer areas. ${ }^{9}$ As far as possible areas and selected primary schools within areas remained in the study; when replacement was necessary either another school in the same area was selected or another area chosen from the same stratum. Trends in height for the 22 English areas from 1972 to 1986 were comparable with those for the 13 areas in which the same schools participated throughout, ${ }^{4}$ but one area in Scotland was by chance replaced by an area in which children were substantially taller.

Areas were visited yearly until 1982, and every two years thereafter. In 1983 the design was modified. Schools in wards in 10 English inner city areas and in 10 areas containing a high proportion of children from ethnic minorities were added and surveyed in alternate years to the original schools. ${ }^{6}$ 
At the same time eight further Scottish areas were included, selected from the original sampling frame. Data for the original quasirepresentative English samples in 1972 and 1986, and for the new Scottish areas and the inner city and ethnic minority areas sample in 1985, have been analysed.

In 1985 the children were classified as white, Afro-Caribbean, Urdu, Gujarati, Punjabi, other Asian, and others, according to the fieldworker's assessment and the language spoken at home. ${ }^{6}$ The few non-white children measured in 1972 were omitted from analysis, as the language spoken at home was not known. Non-white children in the 1986 English sample, and from Scotland, were omitted for the same reason. This eliminated a substantial number of children in just one English area, which had replaced one of the 22 original areas in 1982. Data for children from the original Scottish area and the current non-comparable area that replaced it were omitted completely, so that data were used from five Scottish areas in 1972 and in 1986, and from eight in 1985. The latter eight areas were grouped with the 1986 areas rather than the 1985 English areas because of comparability of method of selection.

The areas selected as inner city areas on the basis of overcrowding, shared amenities, and high rates of unemployment tended to have a higher than average proportion of ethnic minorities, and conversely those selected as Asian or Afro-Caribbean areas tended to have at least one feature of inner city areas. All 20 areas are therefore referred to in the following as inner city areas.

Height was measured on a specially designed stadiometer (Holtain) using the method described by Tanner et $a l^{12}$ and recommended by Weiner and Lourie for the International Biological Programme. ${ }^{10}$ The measurements were made by a school nurse supervised by a trained fieldworker who made an additional quality control measurement on about one in 10 children. Height was recorded to the last complete $0.5 \mathrm{~cm}$ on the scale in 1972 , and to the last $0 \cdot 1 \mathrm{~cm}$ in 1985 and $1986 ; 0.25$ $\mathrm{cm}$ or $0.05 \mathrm{~cm}$ was added to each measurement as appropriate.

As the between child variance of height increases with age, in order to analyse data for all ages a standard deviation (SD) score was calculated for each child, ${ }^{11}$ which was the difference between the child's height and the mean for its age and sex, divided by the age and sex specific standard deviation. Use of the SD score has the additional advantage of immediate conversion to centile score, as height is known to be a normally distributed variable. The means and standard deviations were obtained from 1972 English data by smoothing values calculated from six month age groups. Standard deviations were first adjusted for age grouping as described by Healy, ${ }^{12}$ and means and standard deviations each smoothed using cubic polynominal curves for boys and girls separately. Children outside the age range 4.0 to 12.0 years were excluded, as were those for whom height was not recorded.

Data on the number of children in the family, father's social class, the child's birth weight, and the heights of the parents were obtained from a self administered questionnaire that was usually completed by the child's mother. In 1972 questions concerning social class and parental height referred to 'respondent' and 'spouse' rather than to child's mother and father; therefore there were 'missing' data when the respondent was other than the mother or father. In 1985 and 1986, questions
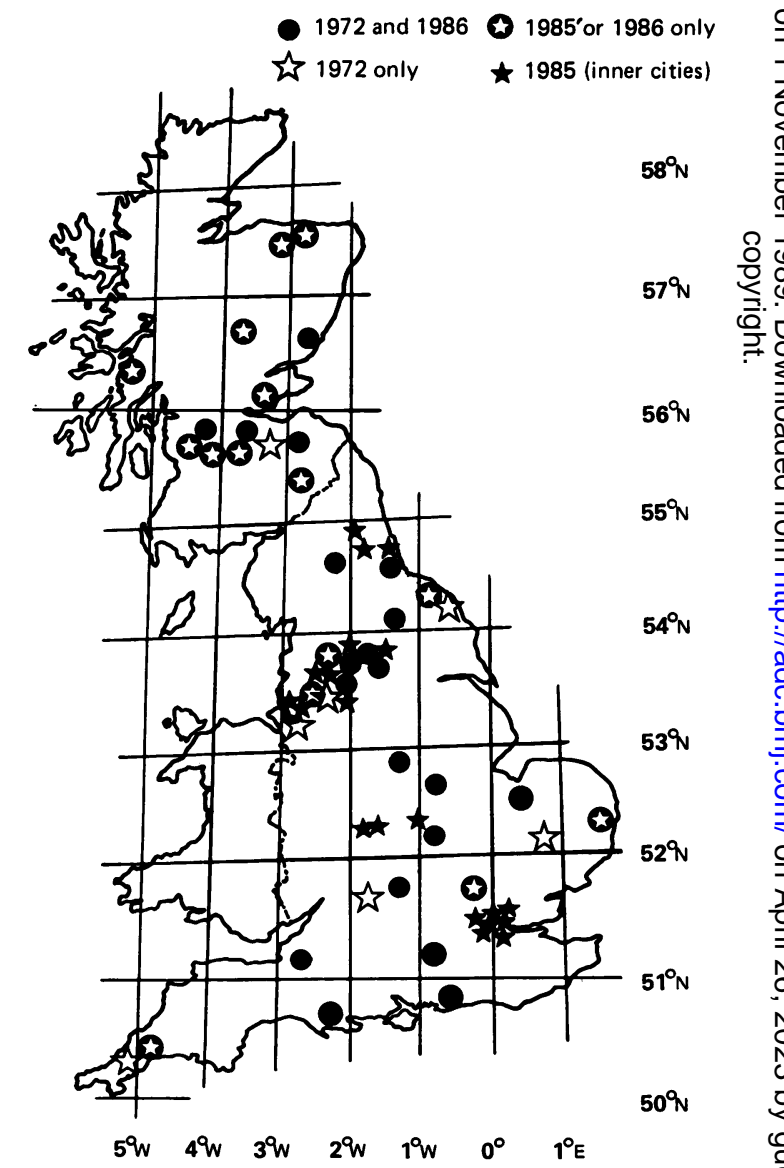

Fig 1 Areas in the National Study for Health and Growth. Changes of school within areas are not shown. 
referred to child's father or male guardian for social class, and to natural mother and father for heights of parents. Family size and father's social class were treated as categorical variables with a missing value category. Birth weight and heights of parents were analysed as continuous variables. Children with missing data were included in the analysis, and mean differences in height SD scores were estimated between children with missing data and those with an average birth weight, mother's height, or father's height.

So that results relating to area of residence would be in a usable form, each National Study for Health and Growth area was assigned its latitude and longitude to the nearest degree (fig 1). Multiple regression analyses were carried out with height SD score as the dependent variable. The independent variables included year group (table 1), accounting for trend over time and inner city selection, and ethnic origin with categories as in table 2, family size (table 3 ), social class (table 4), country (England and Scotland); the continuous variables were birth weight, mother's height, father's height, and latitude and longitude.

SD scores based on the Tanner standards were also calculated so that adjustments to these could be calculated. The published means and standard deviations were interpolated by age using cubic and quartic polynomials respectively. ${ }^{2}$

\section{Results}

The number of boys and girls in each age group for the total 1972 sample, the 1985 English inner city sample, and the Scottish sample for 1985 combined
Table 2 Percentage distribution of children by ethnic group in the National Study for Health and Growth in the English inner city areas in 1985

\begin{tabular}{lrr}
\hline & Boys & \multicolumn{1}{c}{ Girls } \\
\hline White & $37 \cdot 2$ & $35 \cdot 8$ \\
Afro-Caribbean & $13 \cdot 4$ & $14 \cdot 9$ \\
Asian: & $8 \cdot 0$ & \\
Urdu & $9 \cdot 4$ & $9 \cdot 4$ \\
Gujarati & $20 \cdot 6$ & $19 \cdot 6$ \\
Punjabi & $4 \cdot 4$ & $4 \cdot 1$ \\
Other & $7 \cdot 1$ & $7 \cdot 9$ \\
All other & 3304 & 3216 \\
\hline Total No of children & & \\
\hline
\end{tabular}

with the total 1986 sample are shown in table 1 . Numbers of children in school fell between 1972 and $1986,{ }^{4}$ but the eight extra Scottish areas that took part in 1985 compensated for the decrease. Table 2 shows the distribution of children in the 1985 English inner city sample by ethnic group. All Asians outnumbered white children, but the latter was the largest group in the inner city sample, followed by the Punjabi speaking Asians.

Table 3 shows the distribution of children by family size in each of the three samples. Average family size decreased between 1972 and 1986, confirmed by the previous analysis of areas continuing in the study. ${ }^{4}$ Despite the greater proportion of missing data, family size was found to be greater in the inner city areas sample, particularly among Asian groups.

Table 4 shows the distribution of children by father's social class. There was a shift from manual

Table 1 Distribution of children by age and sex in the National Study for. Health and Growth in the quasirepresentative samples in 1972 and 1985/86 and in the English inner city areas in 1985

\begin{tabular}{|c|c|c|c|c|c|c|}
\hline \multirow{2}{*}{$\begin{array}{l}\text { Age } \\
\text { group } \\
\text { (years) }\end{array}$} & \multicolumn{3}{|l|}{ Boys } & \multicolumn{3}{|l|}{ Girls } \\
\hline & $\begin{array}{l}1972 \\
\text { England and } \\
\text { Scotland }\end{array}$ & $\begin{array}{l}1985 \\
\text { England } \\
\text { (inner city) }\end{array}$ & $\begin{array}{l}\text { Scotland } 1985 \\
\text { and England } \\
\text { and Scotland } \\
1986\end{array}$ & $\begin{array}{l}1972 \\
\text { England and } \\
\text { Scotland }\end{array}$ & $\begin{array}{l}1985 \\
\text { England } \\
\text { (inner city) }\end{array}$ & $\begin{array}{l}\text { Scotland } 1985 \\
\text { and England } \\
\text { and Scotland } \\
1986\end{array}$ \\
\hline $4<<5$ & 120 & 122 & 168 & 123 & 99 & 132 \\
\hline $5-<6$ & 721 & 535 & 769 & 715 & 492 & 687 \\
\hline $6-<7$ & 754 & 472 & 831 & 714 & 503 & 708 \\
\hline $7-<8$ & 802 & 507 & 766 & 777 & 441 & 707 \\
\hline $8<<$ & 740 & 447 & 700 & 708 & 477 & 650 \\
\hline $9-<10$ & 780 & 447 & 703 & 680 & 444 & 647 \\
\hline $10-<11$ & 743 & 451 & 751 & 730 & 466 & 733 \\
\hline $11-<12$ & 434 & 323 & 480 & 413 & 294 & 469 \\
\hline Total & 5094 & 3304 & 5168 & 4860 & 3216 & 4733 \\
\hline
\end{tabular}


Table 3 Percentage distribution of children by size of family in the National Study for Health and Growth in the quasirepresentative samples in 1972 and 1985/86 and in the English inner city areas in 1985

\begin{tabular}{|c|c|c|c|c|c|c|}
\hline \multirow{2}{*}{$\begin{array}{l}\text { No of } \\
\text { children } \\
\text { in family }\end{array}$} & \multicolumn{3}{|l|}{ Boys } & \multicolumn{3}{|l|}{ Girls } \\
\hline & $\begin{array}{l}1972 \\
\text { England and } \\
\text { Scotland }\end{array}$ & $\begin{array}{l}1985 \\
\text { England } \\
\text { (inner city) }\end{array}$ & $\begin{array}{l}\text { Scotland } 1985 \\
\text { and England } \\
\text { and Scotland } \\
1986\end{array}$ & $\begin{array}{l}1972 \\
\text { England and } \\
\text { Scotland }\end{array}$ & $\begin{array}{l}1985 \\
\text { England } \\
\text { (inner city) }\end{array}$ & $\begin{array}{l}\text { Scotland } 1985 \\
\text { and England } \\
\text { and Scotland } \\
1986\end{array}$ \\
\hline 1 & $6 \cdot 6$ & $6 \cdot 4$ & $8 \cdot 4$ & $6 \cdot 4$ & $6 \cdot 3$ & $8 \cdot 5$ \\
\hline 3 & $24 \cdot 4$ & $21 \cdot 1$ & $24 \cdot 5$ & $25 \cdot 1$ & $17 \cdot 8$ & $24 \cdot 4$ \\
\hline 4 & $14 \cdot 1$ & $13 \cdot 2$ & $7 \cdot 9$ & $13 \cdot 0$ & $14 \cdot 4$ & $9 \cdot 4$ \\
\hline 5 & $7 \cdot 2$ & $8 \cdot 4$ & $2 \cdot 3$ & $7 \cdot 1$ & $8 \cdot 8$ & $2 \cdot 4$ \\
\hline 6 & $2 \cdot 8$ & $4 \cdot 6$ & $1 \cdot 0$ & $3 \cdot 2$ & $5 \cdot 1$ & $1 \cdot 0$ \\
\hline 7 & $1 \cdot 2$ & $1 \cdot 7$ & 0.5 & $1 \cdot 7$ & $2 \cdot 5$ & $0 \cdot 3$ \\
\hline 8 or more & $1 \cdot 5$ & $2 \cdot 0$ & $0 \cdot 1$ & $1 \cdot 8$ & $2 \cdot 0$ & $0 \cdot 1$ \\
\hline Not known & $12 \cdot 0$ & 23.4 & $8 \cdot 5$ & $11 \cdot 7$ & $24 \cdot 3$ & $7 \cdot 9$ \\
\hline
\end{tabular}

Table 4 Percentage distribution of children by father's social class in the National Study for Health and Growth in the quasirepresentative samples in 1972 and 1985/86 and in the English inner city areas in 1985

\begin{tabular}{|c|c|c|c|c|c|c|}
\hline \multirow{2}{*}{$\begin{array}{l}\text { Father's } \\
\text { social } \\
\text { class }\end{array}$} & \multicolumn{3}{|l|}{ Boys } & \multicolumn{3}{|l|}{ Girls } \\
\hline & $\begin{array}{l}1972 \\
\text { England and } \\
\text { Scotland }\end{array}$ & $\begin{array}{l}1985 \\
\text { England } \\
\text { (inner city) }\end{array}$ & $\begin{array}{l}\text { Scotland } 1985 \\
\text { and England } \\
\text { and Scotland } \\
1986\end{array}$ & $\begin{array}{l}1972 \\
\text { England and } \\
\text { Scotland }\end{array}$ & $\begin{array}{l}1985 \\
\text { England } \\
\text { (inner city) }\end{array}$ & $\begin{array}{l}\text { Scotland } 1985 \\
\text { and England } \\
\text { and Scotland } \\
1986\end{array}$ \\
\hline I & 3.5 & 0.8 & $5 \cdot 0$ & $3 \cdot 4$ & 1.0 & $4 \cdot 0$ \\
\hline II & $11 \cdot 2$ & $5 \cdot 6$ & $20 \cdot 9$ & $10 \cdot 7$ & 4.9 & $20 \cdot 0$ \\
\hline III non-manual & 7.2 & $2 \cdot 7$ & $6 \cdot 6$ & $6 \cdot 7$ & $2 \cdot 7$ & $7 \cdot 6$ \\
\hline III manual & $35 \cdot 6$ & $23 \cdot 9$ & $33 \cdot 2$ & $34 \cdot 8$ & $24 \cdot 9$ & $32 \cdot 1$ \\
\hline IV & $10 \cdot 2$ & $15 \cdot 5$ & $9 \cdot 5$ & $10 \cdot 9$ & $14 \cdot 6$ & $11 \cdot 1$ \\
\hline $\mathrm{V}$ & 4.8 & $5 \cdot 1$ & $2 \cdot 9$ & 4.7 & $4 \cdot 7$ & $3 \cdot 1$ \\
\hline \multicolumn{7}{|l|}{ Armed forces and } \\
\hline unclassifiable & $6 \cdot 0$ & 0.7 & 0.9 & $6 \cdot 1$ & 0.4 & $0 \cdot 8$ \\
\hline No father in home & $4 \cdot 6$ & $15 \cdot 8$ & $10 \cdot 1$ & $4 \cdot 5$ & $15 \cdot 8$ & $10 \cdot 3$ \\
\hline Not known & $16 \cdot 8$ & $29 \cdot 8$ & $10 \cdot 9$ & $18 \cdot 1$ & $31 \cdot 0$ & $11 \cdot 1$ \\
\hline $\begin{array}{l}\text { Total No of } \\
\text { children }\end{array}$ & 5094 & 3304 & 5168 & 4860 & 3216 & 4733 \\
\hline
\end{tabular}

to non-manual occupations, especially to those in social class II, between 1972 and 1986. This was in line with national trends from 1971 and $1981 .^{13}$ The inner city sample had a higher proportion of semiskilled fathers, and almost certainly a lesser proportion in non-manual and skilled occupations, but conclusions were hampered by the large amount of missing data. In addition there was a higher proportion of single parent (mother) families, greater in the Afro-Caribbean group. There was a rise in one parent families in the quasirepresentative sample from 1972 to 1986 .

Only a small number of children (five boys and seven girls) had a height SD score greater than 4 or less than -4 . These were omitted as they were thought to be erroneous. There was then a total of 13561 boys and 12802 girls measured at one of three surveys and included in the multiple regression analyses.

Father's social class was reduced to the categories non-manual, manual, and not known, with no significant increase in the residual sum of squares, and a worthwhile simplification was achieved by grouping family size into the six categories $1,2,3,4$ or 5,6 or more, or not known.

All the variables in the analysis, with family size 
and father's social class modified as above, were independently significantly associated with height SD score except for the missing value adjustment for father's height for longitude for boys and for father's social class, and the adjustment for missing birth weight for girls. Almost all were highly signficant associations $(p<0 \cdot 001)$.

Table 5 gives the estimated effect on height SD score independently attributed to each of the factors in the multiple regression model. The column on the left for both boys and girls, gives the difference for each variable or category from a white child measured in 1972, with no siblings, father in non-manual occupation, birth weight $3380 \mathrm{~g}$, mother's height $160 \mathrm{~cm}$, father's height $176.5 \mathrm{~cm}$, and living near $50^{\circ} \mathrm{N} 5^{\circ} \mathrm{W}$. The column on the right for both boys and girls, gives the corresponding figures when only the biological variables (ethnic origin, birth weight, and parental heights) and sample selection and trend over time are taken into account. This table is given primarily to illustrate the importance of each factor, but can also be used to calculate an expected height SD score, as illustrated in table 6 for two rather extreme cases.

This is not to say that either such child exists. The 'total' line gives SD score in units applicable to all children, as non-conditional standards have generally been calculated. As the factors in the left hand column in table 5 account for about $23 \%$ of the variation, however, it is necessary to judge a child against the variation around his or her group mean to use the table to provide a proper conditional height SD score. By dividing by the residual within group standard deviation, which is less than one SD score in the above units, a conditional SD score is obtained. The final line of table 5 gives the necessary divisor, which gives the final SD score. If the first child was 7.8 years old and $123.9 \mathrm{~cm}$ tall, and so at the 50th centile (nominal SD score $=0.0$ ) as judged by the Tanner standards ${ }^{12}$ or Rona and

Table 5 Estimated difference in height SD scores from a white child measured in 1972, with no siblings, father in non-manual occupation, birth weight $3380 \mathrm{~g}$, mother's height $162 \mathrm{~cm}$, father's height $176.5 \mathrm{~cm}$, and living in Cornwall $\left(50^{\circ} \mathrm{N} 5^{\circ} \mathrm{W}\right)$

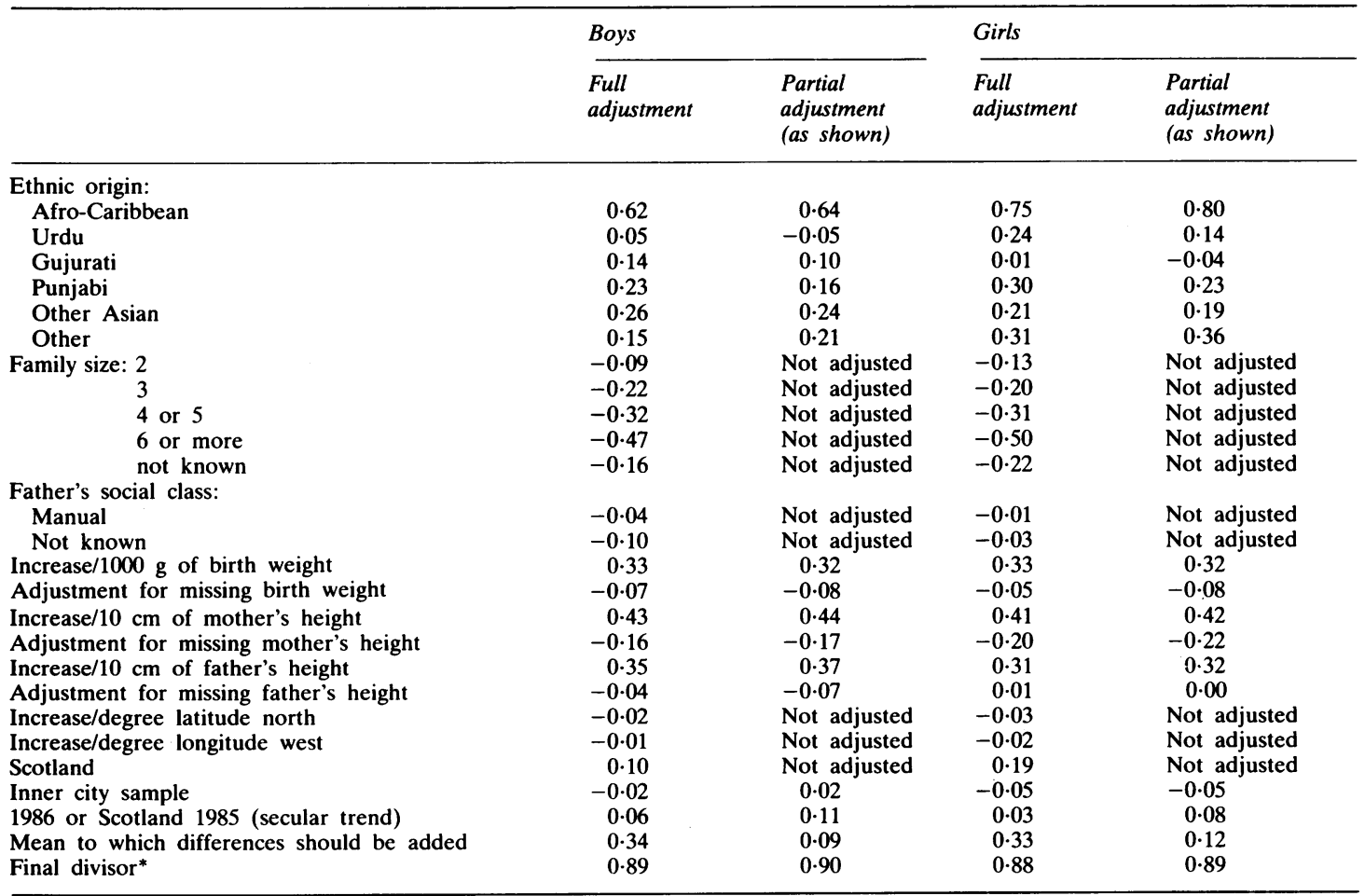

*See text. 
Table 6 Two examples of expected height SD score calculation using the full adjustment estimates from table 5

\begin{tabular}{|c|c|c|c|c|}
\hline & \multicolumn{2}{|l|}{ First child } & \multicolumn{2}{|c|}{ Second child } \\
\hline & $\begin{array}{l}\text { Child's } \\
\text { data }\end{array}$ & $\begin{array}{l}\text { Contribution } \\
\text { to expected } \\
\text { SD score }\end{array}$ & $\begin{array}{l}\text { Child's } \\
\text { data }\end{array}$ & $\begin{array}{l}\text { Contribution } \\
\text { to expected } \\
\text { SD score }\end{array}$ \\
\hline Sex & Female & Not applicable & Male & Not applicable \\
\hline Ethnic origin & Afro-Caribbean & +0.75 & White & Not applicable \\
\hline Family size & 1 & Not applicable & 6 & -0.47 \\
\hline Father's social class & Non-manual & Not applicable & Manual & -0.04 \\
\hline Birth weight & $4380 \mathrm{~g}$ & +0.33 & $2380 \mathrm{~g}$ & $-0 \cdot 33$ \\
\hline Mother's height & $172 \mathrm{~cm}$ & +0.41 & $157 \mathrm{~cm}$ & $-0 \cdot 215$ \\
\hline Father's height & $181.5 \mathrm{~cm}$ & $+0 \cdot 155$ & $166.5 \mathrm{~cm}$ & $-0 \cdot 35$ \\
\hline Latitude & $51^{\circ} \mathrm{N}$ & -0.03 & $55^{\circ} \mathrm{N}$ & $-0 \cdot 10$ \\
\hline Longitude & $0^{\circ}$ & $+0 \cdot 10$ & $3^{\circ} \mathrm{W}$ & +0.02 \\
\hline Country & England & No applicable & England & Not applicable \\
\hline Inner city & Yes & -0.05 & No & Not applicable \\
\hline Year & 1985 & Not applicable & 1986 & +0.06 \\
\hline 'Mean' & $0 \cdot 33$ & $0 \cdot 33$ & $0 \cdot 34$ & $0 \cdot 34$ \\
\hline Total & & 1.995 & & $-1 \cdot 085$ \\
\hline Final divisor* & $0 \cdot 88$ & & $0 \cdot 89$ & \\
\hline
\end{tabular}

${ }^{*}$ See text.
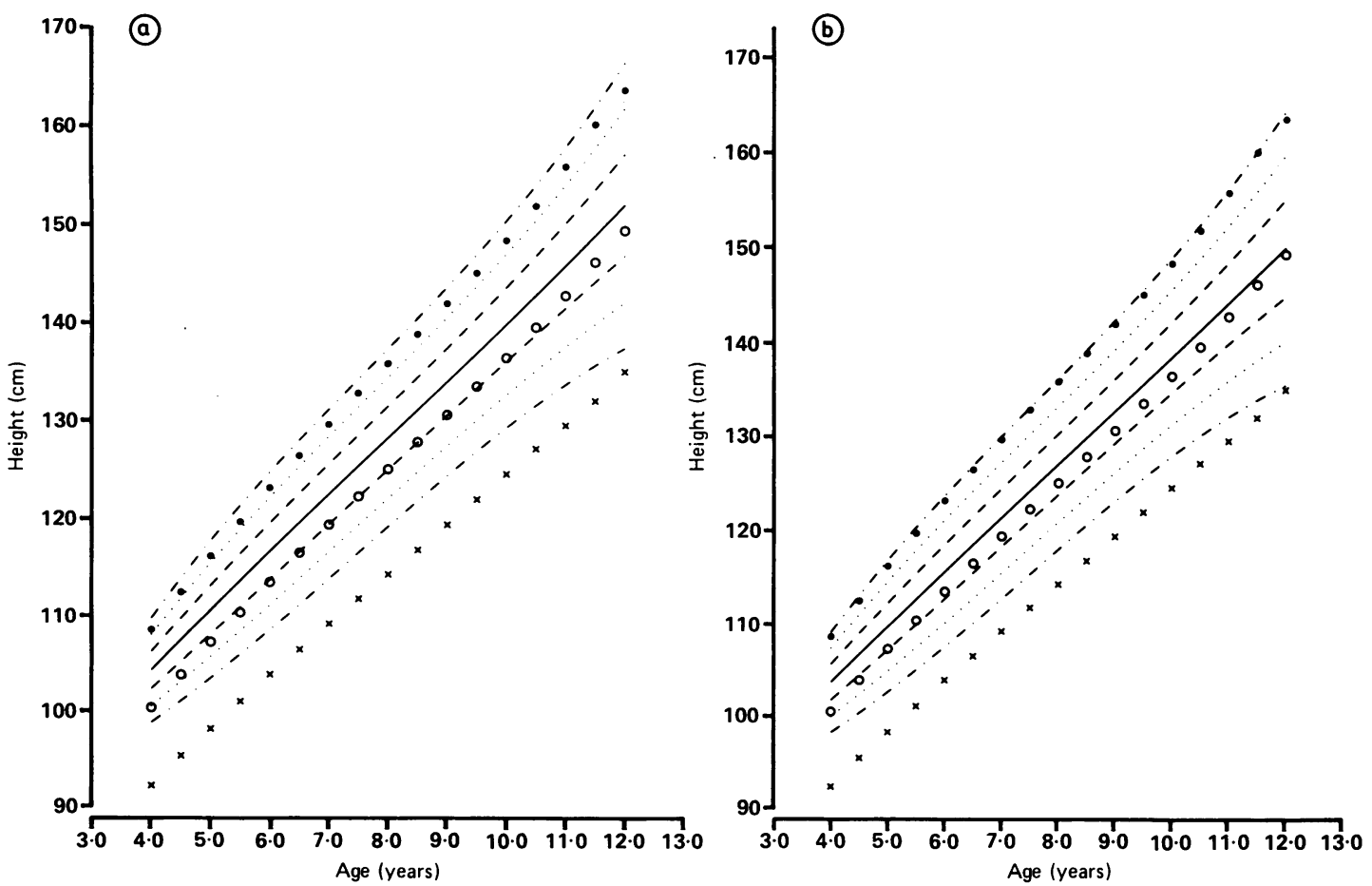

Fig 2 Comparision of 1986 reference centiles (3rd, 10th, 25th, 50th, 75th, 90th, 97th) for two white girls: birth weight $3380 \mathrm{~g}$, mother's height $162 \mathrm{~cm}$, father's height $176.5 \mathrm{~cm}$, with no siblings, and father in non-manual occupation; (a) living near $51^{\circ} \mathrm{N} 1^{\circ} \mathrm{E}$ and $(b)$ living near $55^{\circ} \mathrm{N} 3^{\circ} \mathrm{W}$. Centiles: 3rd and 97th-.-; 10th and 90th $\cdots \cdots ; 25$ th and 75 th - - ; and 50th - Tanner 3rd (×), 50th (O), and 97th (O) centiles. 
Altman, ${ }^{8}$ then she would have a conditional SD score of $-2 \cdot 27$, which is a little above the 1 st centile. If of nominal SD score $(1 \cdot 0)$, then her conditional SD score would be $(1-1 \cdot 995) / 0 \cdot 88=-1 \cdot 13$, which is just above the 10 th centile.

Table 5 (left hand columns) show that ethnic origin, family size, birth weight, and heights of parents may be of considerable importance in the assessment of a child, but that social class and trend over time are of little importance when these other factors have been taken into account. The columns on the right, in comparison, show that birth weight and parental height adjustments are stable, but that ethnic origin adjustments depend on the other variables in the analysis, the differences being mainly due to the omission of family size in these columns.

The maximum effect of area of residence in England, from the south east at $51^{\circ} \mathrm{N} 1^{\circ} \mathrm{E}$ to the north west at $55^{\circ} \mathrm{N} 3^{\circ} \mathrm{W}$ was $0 \cdot 15 \mathrm{SD}$ score for boys and 0.22 SD score for girls, and is shown for girls in fig 2; estimated from the rounded figures in table 5 the effect was $0 \cdot 12$ and $0 \cdot 20$ SD score, respectively. Each of these centile lines is for a white child with no siblings, father in non-manual occupation, and with average birth weight and parental heights. They have been adjusted for the secular trend; the Tanner 3rd, 50th, and 97th centiles are shown for comparison. The centile curves in fig 2 are closer together than the Tanner centiles because they are each given for fixed values of the biological and social variables.

The mean adjustment for secular trend to the unconditional Tanner standards for white children was estimated to be $0 \cdot 20$ SD score for boys and girls. Variation in heights of white children was reduced, so that the adjusted Tanner SD score should then be divided by 0.93 for boys, and 0.92 for girls, in order to retain a standard deviation of 1.0 . The net result is of little change in the 97th centile, but a substantial increase in the 3 rd centile. The adjustments are not entirely independent of age, however, as they represent a mean change ranging from just over half a centimetre in the youngest girls to over a centimetre in the oldest boys.

\section{Discussion}

Standards for height are required for the assessment of short stature, and, to a lesser extent, tall stature. Failure of growth may have various causes, of which the most important are chronic disorders including endocrine conditions amenable to treatment, and social and psychological problems. Recently treatment with growth hormone was shown to be effective for 'short normal' children, ${ }^{14}$ although the outcome for final height is unknown. Most tall children do not suffer from any pathological condition, but treatment may be sought to prevent embarrassment. Whatever the eventual diagnosis and intervention (if any), the immediate presenting problem is the same, that of the initial assessment of the height of the child in relation to his or her age group as a whole, and in comparison with whatever subgroup is most appropriate. It is with the initial assessment that this paper is concerned, and not with follow up assessments for which height velocity standards, ${ }^{12}$ longitudinal standards, ${ }^{15}$ or previous height conditional standards ${ }^{16}$ should be used.

The primary aim is therefore to minimise delay in treatment or intervention for those for whom it is appropriate, although large numbers of unnecessary referrals to paediatric clinics or follow up appointments are also undesirable. The cut off point below which a child is referred or followed up should therefore maximise detection of treatable conditions, or some suitable combination of sensitivity and specificity. To optimise the cut off point or estimate the delay in intervention for those not followed up, however, we would need to know the eventual diagnosis for a large number of children. This has a bearing on the question of adjustment for the trend over time and on what factors should be taken into account.

Only information likely to be available when a child is first assessed has been considered in this analysis. Of the variables included, ethnic origin, birth weight, and heights of parents are each independently associated with a child's height to a sufficient extent to require consideration, and when combined should adjust for genetic potential. Secular trend is of relatively little importance, especially if family size is also taken into account. The relation between height and latitude and longitude is sufficient that separate standards for England (north west), England (south east), and Scotland also require consideration. Social class has relatively little effect, but family size is important if it is thought appropriate to take social factors into account. Unfortunately there was some suggestion that the relation of height to family size is associated with ethnic origin, so this is not straightforward.

The significance of the relationship of any factor to height does not automatically imply, however, that it should be taken into account in the assessment. If at a given height Afro-Caribbean children have the same prevalence of treatable conditions, then their overall prevalence will be lower and it is appropriate to use reference curves for white children. In the absence of diagnostic data, however, we must presume that Afro-Caribbean children have a similar prevalence to others and therefore greater prevalence at a given height, and 
that use of standards for white children would cause delay in intervention for those for whom it is appropriate.

It is also reasonable to assume that the prevalance of treatable problems has not decreased over time, so that the trend in height over time requires new unconditional standards for white children.

The difference in mean height SD score of 0.5 between singleton children and those in families of six or more is considerable, but whether it is associated with corresponding differences in the incidence of treatable causes of short stature (which argue against adjustment for family size) is unknown. Information about father's social class is often unobtainable or inappropriate for inner city children, and of small importance among these data when other factors were taken into account.

In the absence of outcome data to optimise cut off points for use in screening there are three possible strategies. One is to use the same reference curves for all children basing them on data representative of the whole population on the assumption that height differences between groups reflect differences in the prevalence of treatable conditions. In effect this has been the policy when the unconditional Tanner standards have been used alone. The second is to use conditional standards, and the third is to use standards appropriate to the most advantage group in the belief that these represent the optimal growth that should be the target for all. The first and third strategies may differ in the cut off points actually used, but they do not differ fundamentally. Goldstein and Tanner argued cogently against the third, and in favour of the second strategy on several grounds. ${ }^{7}$ They believed that differences from environmental causes should be treated in groups, and that individual subjects should be screened with standards derived from children of similar genetic background and environment. They recommended subgroups defined in terms of sex, family size, place of residence, ethnic origin, and heights of parents, to which birth weight should be added if their argument is accepted. We accept their argument for genetic effects, but not for environmental ones.

It should be noted that at present conditioning on birth weight and parental heights does not eliminate differences between ethnic groups, although these can be expected to diminish over time. In this limited age range, however, they could reflect differences in age at maturation between ethnic groups.

If unconditional reference curves are required the trend over time is such that revision of the Tanner standards is required. Our minimum estimate of trend between 1972 and 1986 for white children from the 1972 based SD score, was $\mathbf{0 . 1 7}$ for boys and
0.12 for girls, or up to about $1.2 \mathrm{~cm}$ in older boys, and a minimum of $0.6 \mathrm{~cm}$ in younger girls. The trend is greater if estimated from the approximate Tanner SD score. The possible delay in treatment of AfroCaribbean children from the use of standards for white children is undesirable. The National Study for Health and Growth can provide data for only 4 to 12 years, and extrapolation of the trends to other ages should not be assumed. Opposite trends in height in infants and older children have been reported from The Netherlands. ${ }^{17}$ At a minimum, revised standards are required for white and AfroCaribbean children across the whole age range for growth.

We thank all children, parents, teachers, doctors, administrators, nurses, and clerks in the areas and schools for their participation in the study, Professor WW Holland and the fieldworkers and administrators in our department for their work on the study, and Mrs A Childs for producing the manuscript. The study was supported by the Department of Health and the Scottish Home and Health Department.

\section{References}

1 Tanner JM, Whitehouse RH, Takaishi M. Standards from birth to maturity for height, weight, height velocity and weight velocity in British children 1965. Arch Dis Child 1966;41: 454-71.

2 Tanner JM, Whitehouse RH, Takaishi M. Standards from birth to maternity for height, weight, height velocity and weight velocity in British children 1965. Arch Dis Child 1966;41: 613-35.

${ }^{3}$ Chinn S, Rona RJ. The secular trend in the height of primary school children in England and Scotland from 1972-1980. Ann Hum Biol 1984;11:1-16.

4 Chinn S, Rona RJ, Price CE. The secular trend in height of primary school children in England and Scotland 1972 to 1979 and 1979 to 1986. Ann Hum Biol (in press).

5 Voss LD, Wilkin TJ, Betts PR. Do we need new growth charts? Lancet 1987;ii:447-8.

- Rona RJ, Chinns S. National Study for Health and Growth: social and biological factors associated with height of children from ethnic groups living in England. Ann Hum Biol 1986;13: 453-71.

7 Goldstein H. Tanner JM. Ecological considerations in the creation and the use of child growth standards. Lancet 1980;i: $582-5$.

${ }^{8}$ Rona RJ, Altman DG. National Study for Health and Growth. Standards of attained height, weight and triceps skinfold in English children 5 to 11 years old. Ann Hum Biol 1977:4: 501-23.

${ }^{9}$ Irwig LM. Surveillance in developed countries with particular reference to child growth. Int J Epidemiol 1976;5:57-61.

10 Weiner JS, Lourie JA. Human biology, a guide to field methods. International Biological Programme Handbook No 9. Oxford: Blackwell Scientific Publications, 1969.

1 Rona RJ, Swan AV, Altman DG. Social factors and height of primary school children in England and Scotland. $J$ Epidemiol Community Health 1978:32:147-54.

12 Healy MJR. The effect of age-grouping on the distribution of a measurement affected by growth. Am J Phys Anthropol 1962;20:47-50.

13 Beacham R. Economic activity: Britain's workforce 1971-81. Population Trends 1985;37:6-14. 
14 Hindmarsh PC, Brook CGD. Effect of growth hormone on short normal children. Br Med J 1987;295:573-7.

15 Tanner JM, Whitehouse RH. Clinical longitudinal standards for height, weight, height velocity, and stages of puberty. Arch Dis Child 1976;51:170-9.

16 Cameron N. Conditional standards for growth in height of British children from 5.0 to 15.99 years of age. Ann Hum Biol 1980;7:331-7.
17 Roede MJ, van Wieringen JC. Growth diagrams 1980. Tijdschrift voor Sociale Gezondheidszong 1985;63(suppl):1-34.

Correspondence to Miss S Chinn, Department of Community Medicine, United Medical and Dental Schools of Guy's and St Thomas's Hospitals, St Thomas's Campus, London SE1 7EH.

Accepted 26 May 1989 